Ouest Africains-organized by the Institut Français d'Afrique Noire (IFAN). He had the honour of being invited to serve as one of the three vice-presidents, the other two being Professor Théodore Monod and Professor Santa-Olalla of Madrid. The President was Professor Auguste Chevalier, the veteran French biologist of the Musée d'Histoire Naturelle, who travelled from Paris. At a public session Professor Forde delivered an address in French on ' The Contribution of Ethnography to African Development', in the course of which he outlined the plans for an Ethnographic Survey to be carried out, so far as West Africa is concerned, by the Institute in collaboration with IFAN. The Conference was not confined to anthropology but embraced all field studies and such subjects as national parks for the preservation of the fauna of West Africa. Papers were contributed by French, Portuguese, Spanish and British savants and administrators. A list of these papers can be consulted in our London office. Two half-days were devoted to West African ethnology and archaeology, during which there were valuable exchanges of views on such questions as the contribution of ethnological studies to the solution of problems arising from the division of peoples by international boundaries, the need for clearer distinction in field studies and reports between family, household and lineage groupings, and the recording and preservation of rock paintings.

The Conference formally constituted itself as the International Conference of West Africanists and set up an organizing committee to prepare for another gathering-it is hoped to hold one every other year from 1946. The members of the committee are as follows: representing French Africa, Professor Théodore Monod; British West Africa, A. E. Southern; Spain, metropolitan and colonial, Professor J. Martínez Santa-Ollala; Portugal, metropolitan and colonial, Professor A. A. Mendes-Correa; Great Britain, Professor Daryll Forde; France, Professor Paul Rivet. The Conference is divided into five sections viz. (I) the physical environment: physical geography; geology; human geography; economic geography; climatic factors; (2) the biological environment: ecology; biological oceanography; zoology; botany; (3) the human environment: physical anthropology (morphological and functional); linguistics; folk-lore; ethnography; African arts; sociology, religion, law; problems of contact; (4) national parks; historical monuments; ( $s$ ) research and its auxiliaries: laboratories, libraries, museums, \&c.

Among the resolutions adopted at Dakar we may quote the following: 'La C.I.A.O. désire insister sur l'urgente nécessité qu'il y a à poursuivre les études ethnologiques systématiques en Afrique occidentale. La transformation toujours plus rapide des conditions sociales et économiques parmi les nombreuses populations intéressées exige un programme immédiat de recherches, à la fois pour recueillir les données scientifiques qui disparaissent rapidement et pour assurer à la science la contribution majeure qu'elle doit apporter à la solution des problèmes sociaux ouest-africains.'

\title{
Proposals for the Revision of the Constitution of Nigeria
}

We draw our readers' attention to Sir Bernard Bourdillon's article in this number. One is apt to forget that until thirty-one years ago Nigeria did not exist as a single political entity. Within the memory of men now living there was indeed no 'Nigeria'. In an area equal to that of France, Belgium, and the United Kingdom put together, a population which is double that of the Dominion of Canada is divided into numerous heterogeneous groups. There are considerable African states with a highly organized political structure. There are also tribes with very simple social organization. At least three hundred languages are spoken. The only bond of unity is that superimposed by Britain. Ever since Lord Lugard's epoch-making governorship the problem has remained of making that unity real-a living thing which might progress from varying stages of adolescence to adult nationhood. The present governor, Sir Arthur Richards, has now put forward proposals with a threefold 
object, namely: to promote the unity of Nigeria; to provide adequately within that unity for the diverse elements which make up the country; and to secure greater participation by Africans in the discussion of their own affairs. He plans to achieve these objects in two ways: first, by widening the scope and membership of the central Legislative Councilempowering it to legislate for the whole territory, north and south, linking it constitutionally with the native authorities, and so constituting it as to allow for an unofficial and African majority. In the second place, it is proposed to set up three Regional Councils, one for each of the Northern, Western, and Eastern provinces.

The two most significant innovations are (I) the linking up of the native authorities with the Legislative Council through the regional Councils; and (2) the unofficial, African, majority in the Legislative Council: as British colonial history shows, this is the step which marks the transition towards responsible government. It is noteworthy that Sir Arthur Richards does not propose to adopt ballot-box methods; outside the Lagos colony, where these are already established, representation in the Councils will conform closely to African patterns.

The progressive modernization of the native authorities is an essential part of the policy which the Governor puts forward. 'The system of indirect rule cannot be static; it must keep pace with the development of the country and it must find a place for the more progressive and better educated men.' He calls for a more resolute fostering of formal meetings of village, district, and provincial Councils as part of the system of native administration, for ' it is in these councils that the habit of political thought will be inculcated so as to make possible the wise choice of the provincial members of the Houses of Assembly'.

The Governor's dispatch containing these proposals was published in March as a White Paper (Cmd. 6599). It was the subject of a day's debate in the Nigerian Legislative Council on 23 March, after which the unofficial members unanimously gave the proposals their support while suggesting amendments on some minor points.

\section{The Atlantic and Africa}

IN a lecture delivered at Duala on the influence of the Atlantic upon Africa, Professor Théodore Monod, Directeur de l'Institut Français d'Afrique Noire, spoke of that ocean as having all through its history cut the world in two. Geography does not offer a complete explanation of this fact. It is largely a human problem. On neither coast did people ever build a boat that could cross the ocean. The out-rigger canoe common in the East has never to our knowledge appeared on the Atlantic littoral. So far as Africa is concerned culture has moved from East to West, not in the reverse direction, and it has moved over the land, not over the sea. Professor Monod proceeds:

' Je sais bien que l'on a voulu, sous le nom de culture atlantique, définir une civilisation ouest-africaine, celle des Baoulés, des Ashantis, du Dahomey, des Yorubas et du Bénin, dont les éléments méditerranéens ou orientaux, indéniables, seraient venus par mer. On l'a redit tout récemment du parasol emblème de la royauté et du lion héraldique et il fut un temps où l'on supposait même que le procédé de la tonte à la cire perdue avait été enseigné aux artistes du Bénin par les Portugais du Xvi ${ }^{e}$ siècle. Je ne crois guère à l'influence culturelle de navigations commerciales anciennes, elles-mêmes d'ailleurs plus que problématiques, sur la côte occidentale d'Afrique et qu'aucun fait archéologique n'est encore venu appuyer.

' On ne saurait par contre exagérer le rôle, constant, et dès les temps les plus reculés, dès la préhistoire, des courants humains qui ont pénétré et "imbibé" l'Afrique noire à partir de la Méditerranée, à travers un Sahara demeuré de siècle en siècle un actif et vivant truchement entre la Berbérie et le Soudan, à partir du Nil aussi, de l'Abyssinie, de la mer Rouge, puis, par delà ce médiocre caniveau, de l'Arabie et, comme dirait l'indicateur de chemin de fer, des " au delà ".' 